Jarosław Moskałyk ${ }^{1}$

Uniwersytet im. Adama Mickiewicza w Poznaniu, Polska

Wydział Teologiczny

\title{
Dzisiejsza obecność teologa i teologii we wspólnocie akademickiej
}

Dzisiejszy kontekst kulturowy, społeczny, cywilizacyjny i ogólnie naukowy stawia otwarte pytanie o obecność teologa i sens promowania teologii w naukowych ośrodkach akademickich. Jeśli teolog jest jeszcze w stanie zdobyć jakiś stopień tolerancji i zaufania, to teologia wydaje się stać na zupełnie straconej pozycji. A w gruncie rzeczy chodzi tu o sprawy tożsame oraz wynikające bezpośrednio z tego samego źródła ontologicznego. Zasadniczy problem leży w statusie teologii jako dziedziny naukowej oraz teologu jako naukowcu. Choć jest to trudność niedzisiejsza, to w ostatnim okresie nabiera ona coraz większej wagi i powoduje różne rozterki w świecie naukowym: jak tę całą rzeczywistość traktować i co z nią dalej. Ta sytuacja nie napawa szczególnym optymizmem teologów zawodowo zajmujących się nauką i poznaniem teologicznym, ani nie jest przyjazna dla samej teologii ze względu na jej marginalizację. Jakkolwiek trzeba przyznać, że istniejące wątpliwości oraz spory mają poniekąd podłoże wewnętrzne i wiążą się z próbą zacierania granicy między teologami jako obiektywnymi naukowcami a tzw. teologami kaznodziejami czy teologią jako prawdziwą nauką a teologią kerygmatyczną. To zaś ma pośredni wpływ na pogłębianie się tendencji do wyrugowania teologii i teologów z przestrzeni uniwersyteckich jako niezależnych badaczy. Przy tym staje się nośnym hasło o pozanaukowym charakterze teologii przez jej związek z wiarą, czyli sferą ukrytą. Zadaniem teologów jest dowodzenie, że ich miejsce oraz miejsce teologii pośród innych dyscyplin akademickich mają swoje uprawomocnienie w naukowym zgłębianiu i wyjaśnianiu relacji Bóg-człowiek i człowiek-Bóg — jednej z najważniejszych prawd egzystencjalnych ludzkości.

\footnotetext{
${ }^{1}$ Ksiądz prof. dr hab. Jarosław Moskałyk — Zakład Teologii Fundamentalnej, Dogmatycznej i Ekumenizmu WT UAM w Poznaniu; e-mail: moskalyk@amu.edu.pl. ORCID: 0000-0001-91932433.
} 
Celem niniejszego przedłożenia jest ukazanie rzeczywistych odniesień między teologiem a teologią oraz wypływających stąd konsekwencji. Zostanie również podjęta próba oceny zjawiska oporu względem teologii w środowiskach uniwersyteckich, a także określenia tendencji znoszącej różnice między prawdziwą nauką teologiczną a doktrynalną iluzją parateologiczną. Wreszcie nastąpi wskazanie na możliwości wzajemnego oddziaływania różnych wizji, poglądów i rozwiązań naukowych w ramach jednej struktury i wspólnoty akademickiej.

\section{Obraz teologa w teologii}

Pojęcie 'teolog' obejmuje szerszy zasięg niż to się zwykle przyjmuje i dotyczy tych wszystkich, którzy mają świadomość i potrzebę utożsamienia ze swoją wiarą na sposób żywy. Zgodnie z tą tezą teologiem można być, nie posiadając specjalistycznego czy kierunkowego wykształcenia. Niemniej dochodzi tu często do pomieszania kompetencji z prostym uzmysłowieniem wartości religijnych. Są to całkiem różne rzeczy, dlatego osoby stojące niejako na przeciwległych biegunach posługują się również własnymi kryteriami rozpoznawania warstw religijnych ${ }^{2}$. Przykładowo człowiek odwołujący się jedynie do indywidualnych przemyśleń i refleksji nad wiarą opiera się na innej wiedzy niż ten, który oddał się analizie, badaniom, interpretacji i krytyce zjawiska wiary ${ }^{3}$. Przy tym nie należy zapominać, że osoby zachowujące daleko idącą pewność co do swego zmysłu teologicznego (rozmaici charyzmatycy), lecz pozostające bez żadnego wykształcenia, stają się potencjalnie o wiele większym zagrożeniem dla rzetelnej nauki teologicznej. W tym przypadku twierdzenie, że na teologii zna się każdy chrześcijanin ze względu na związek lub przynależność, jest chybione.

Systematyka i metodologia naukowa wymagają jednak wykształcenia w zakresie dziedziny teologicznej ${ }^{4}$. Oznacza to, że przedmiotem teologii mogą się zajmować osoby posiadające specjalistyczne przygotowanie i predyspozycje teologicznego działania twórczego. Tylko te osoby mogą podnosić teologię na odpowiedni poziom w życiu Kościoła jako wydarzeniu dynamicznym. Teologowie tworzą z myślą o budowaniu i umacnianiu relacji Objawienia oraz Kościoła z człowiekiem otwartym i poszukującym 5 . Wprawdzie stopień opanowania po-

2 Por. R. Bernhard, Ende des Dialogs? Die Begegnung der Religionen und ihre theologischen Reflexion, Zürich 2005, s. 178-183.

${ }^{3}$ Por. P. Roszak, Dwie prędkości teologii? O celu, metodzie i perspektywach teologii analitycznej, „Teologia w Polsce” 9 (2015) 2, s. 75-93.

${ }^{4}$ M. Olszewski, Teologia jako nauka wedlug Tomasza z Akwinu jak też o pożytkach ptynacych z czytania średniowiecznych tomistów, w: Teologia św. Tomasza z Akwinu dzisiaj, red. B. Kochaniewicz, Poznań 2010, s. 137-150.

${ }^{5}$ Por. A. Nossol, Znaczenie ekumenizmu dla wychowania $w$ sytuacji pluralizmu światopogladowego i religijnego, „Paedagogia Christiana” 8 (2001) 2, s. 29-34. 
szczególnych dziedzin teologicznych może być różny, bez względu na podział na osoby duchowne i świeckie, lecz za każdym razem dokumentuje on naukę stosowaną. Jest to tym istotniejsze w perspektywie akademickiej, że podnosi prestiż samej teologii oraz nadaje teologom właściwe miejsce w strukturach uczelnianych. Jeśliby do tego dodać wyrazistość przekazu teologicznego, z czym niestety $\mathrm{z}$ różnych przyczyn nie jest najlepiej, to można by bez obaw patrzeć w przyszły rozwój „teologii uniwersyteckiej”.

Ponieważ w sensie ścisłym aktywność badawczą w zakresie teologii podejmują specjaliści dysponujący odpowiednim warsztatem naukowym i intencją twórczą, przede wszystkim w celu umacniania więzi między prawdami wiary a poznaniem rozumowym, więc od nich w dużej mierze zależy sposób postrzegania Kościoła na zewnątrz. W tym tego Kościoła, który środowisko akademickie traktuje często jako swój, a tych którzy jawią się posłańcami idei teologicznej pośród wielu innych dyscyplin jako swoich partnerów naukowych. Dlatego teolog musi znać, a najlepiej rozwijać własną doktrynę w ramach pewnego systemu, który będzie konkurencyjny wobec innych systemów naukowych ${ }^{7}$. W ten sposób uwolni się od pokusy spłycania i upraszczania całościowej refleksji teologicznej, co stanowi dziś poważne wyzwanie w obliczu niekiedy uzasadnionej krytyki dziedziny teologicznej na uniwersytetach, że jest zbyt enigmatyczna, miałka i pozorowana, a uprawiający ją stają się wyniośli, zarozumiali i nadto pewni siebie. Nierzadko dystansują się od prawdziwego świata nauki, ponieważ postrzegają go jako zagrożenie dla siebie samych i swoich mrocznych teorii.

Najprawdopodobniej tego rodzaju opinie o teologii uniwersyteckiej, jakkolwiek przeniknięte subiektywizmem i może nawet uprzedzeniem, mają swoje podstawy w utożsamianiu teologii wyłącznie z kerygmą bądź wykładnią o urzędzie kościelnym. Jest w tym część odpowiedzialności teologów, którzy nieraz w swoich rozprawach oraz dydaktyce nie potrafią wznieść się ponad kerygmatykę, komentatorstwo i referowanie. Gdzie wyraźnie brakuje jasności systemowej, elementu krytyki, polemiki itd., zdarza się, że dochodzi nawet do pomieszania hierarchii prawd dogmatycznych $\mathrm{z}$ infantylnymi opowieściami natury religijnej. To z pewnością nie służy teologii ani w żaden sposób nie uszlachetnia tzw. teologów uniwersyteckich, a co najwyżej zrównuje ich z funkcją odtwórcy obcych idei czy po prostu podręcznikowego lektora. Przy takiej postawie nie sposób wykształcić w sobie osobowość teologa, rozwinąc charyzmat teologiczny ani tym bardziej rościć pretensje szczególnego uznania w środowisku akademickim.

${ }^{6}$ Por. C. Rychlicki, Proces Boloński. Dziedzictwo kulturowe i wartości akademickie Uniwersytetów Europejskich, ,Roczniki Teologiczne KUL” 54 (2007) 2, s. 231-235.

${ }^{7}$ Zob. J. Werbick, Wissenschaftlich oder kirchlich? Eine Positionsbestimmung der Theologie, „HerKor” Speziel 2 (2008), s. 2-6. 
Między teologiem a teologią musi zachodzić głęboka więź, aby móc spełnić dziejową rolę w stosunku do Boga, człowieka i świata. Teolog winien starać się coś wnosić do teologii, wtedy też teologia może mu więcej ofiarować. Prawidłowe przedstawienie horyzontu teologicznego pozwala patrzeć na problemy religijne w sposób żywy i refleksyjny. Jednocześnie umożliwia kształtować zdrową tkankę myślenia teologicznego we wspólnocie wierzących czy również daleko poza nią oraz ostatecznie odbudowywać jakże potrzebną ufność w krytyczną świadomość teologiczną wśród samych teologów i w szerokim świecie naukowym.

\section{Teologia na peryferiach nauki}

Niegdyś cała kultura znacząco bazowała na pierwiastku religijnym, tworząc tym samym nierozerwalną więź między sacrum a profanum. Wówczas zwracano często uwagę na naturalne odniesienie i przenikanie dwóch różnych rzeczywistości, lecz zależnych od siebie i stanowiących jedną całość. Teraz już tego nie ma, bo też zasięg religii został wyraźnie zawężony, a język teologiczny ze względu na rozmaite przeobrażenia stał się prawie niezrozumiały. Zjawisko to ma swoją ciągłość, począwszy od okresu oświeceniowego, kiedy teologia i teologowie zaczęli być coraz bardziej spychani na obrzeża doświadczenia naukowego. Z czasem proces ten jedynie się pogłębiał, aż do wzmożonego radykalizmu na przełomie XIX i XX wieku, natomiast osobom zajmującym się teologią „zarezerwowano” rolę piewców porządku kościelnego i obrońców teorii katechizmowych. Sytuacja ta stawiała teologię w wyjątkowo niekomfortowym położeniu, w dodatku bez prawa sprzeciwu wobec istniejącego stanu. Dopiero po II Soborze Watykańskim stosunek ten nieco się zmienił, głównie za sprawą nowego otwarcia w Kościele. Niemniej pewne utarte schematy na temat teologii jako rodzaju niezmiennej ideologii wielu nie przestały fascynować, a niektórych nawet mocno intrygować. Stąd próba zastosowania nowych kryteriów w myśleniu teologicznym i o teologii napotykała na duży opór, w tym po stronie rozumiejących tematykę religijną. $\mathrm{Z}$ tego względu nadal odrzucano wszelkie kontrowersje oraz poważne różnice poglądowe wokół treści dogmatycznych, przede wszystkim w obawie przed pluralizmem teologicznym i propagowaniem rzekomej wolności interpretacyjnej. Nastawienie owo stawiało w trudnej sytuacji badaczy teologicznych o rzetelnym, obiektywnym i krytycznym podejściu do badań i twórczości teologicznej.

Zasadniczy problem leży w jakości przedmiotowego stosunku wobec teologii naukowej i w ogóle intuicji teologicznej ${ }^{8}$. Otóż w środowiskach akademic-

${ }^{8}$ Por. C. Rychlicki, Miejsce i rola teologii w formacji chrześcijańskiej, „Teologia i człowiek” 1 (2003), s. 105-122. 
kich, a tym bardziej nieakademickich, panuje ciągle przekonanie, że teologia jako pewna wiedza pomocnicza względem Objawienia nie może mieć żadnych preferencji odkrywczych. Jej drugoplanowy charakter zależy od zmienności i różnorodności, które stoją w sprzeczności względem wiary i Objawienia jako niezmiennych. Ponieważ w teologii „ludzkiej” do głosu dochodzą elementy tymczasowy i przejściowy, więc te wpływają bezpośrednio na jej znaczenie i przydatność. Ci zaś, którzy zajmują się teologią, bywają niejednokrotnie postrzegani z nieskrywaną rezerwą i nawet podejrzeniem o zastygnięcie w świecie abstrakcji albo w skrajnym wypadku, jednakowoż przez osoby deklarujące głęboką wiarę, jako zagubieni lub oddani na służbę nieczystym mocom.

W takich przypadkach mamy do czynienia z rażącym pomieszaniem rzeczywistości, łącznie z manipulacją świadomością ludzką. Niewątpliwie teologii nie należy zrównywać z wiedzą objawioną, bo nią nie jest, lecz pełni istotną funkcję względem Objawienia. To dzięki teologii wiedza o Objawieniu staje się dostępniejsza człowiekowi, a jego przenikanie zostaje rozciągnięte na ludzkie całościowe bytowanie. Teologia, odgrywając rolę pośrednią między Objawieniem a człowiekiem oraz człowiekiem a Objawieniem, w sposób istotny przyczynia się do zbliżenia i powiązania ze sobą tych dwóch rzeczywistości. Przy tym jako nauka chrześcijańska, o czym często się zapomina, korzystając ciągle z nowych inspiracji innych dziedzin naukowych, jedynie umacnia i rozszerza pole interpretacji prawd objawionych. Pozwala tym samym odczytywać Objawienie w prawdziwym świetle jego oddziaływania na człowieka i świat ${ }^{9}$.

Jeszcze trudniej o uznanie dla teologów i teologii wśród osób z tzw. kręgów pozakościelnych, których dziś we wspólnotach akademickich całkiem sporo, gdzie owa dyscyplina naukowa bywa przedmiotem wyszydzania i pogardy. Nie jest wcale odosobnionym zjawiskiem traktowanie teologów w gronie innych naukowców jako zwykłych karierowiczów, których prześladuje rządza władzy kościelnej albo zdobycia stopnia naukowego. Gorsza rzecz jeśli tego rodzaju opiniom przytakują ludzie pełniący ważne stanowiska w Kościele i tym samym przyłączają się do odbierania teologom elementarnego szacunku i godności. Sprawiają wówczas wrażenie, że teologia jest całkiem zbyteczna, a teologowie wykraczający ponad poziom kaznodziejski - nieprzydatni. To wyraz pewnej zapaści świadomościowej i upadku obyczajowego (zwłaszcza w odniesieniu do teologów z prawdziwego zdarzenia), które mają wpływ na postępującą nihilizację życia religijnego.

Można by zatem się zastanowić, skąd bierze się niezrozumienie dla teologii jako nauki zarówno po stronie różnych warstw naukowych, jak i kościelnych. Jedną z przyczyn jest z pewnością nastawienie na odbiór praktyczny, czyli na-

${ }^{9}$ M. Rusecki, Objawienie Boże podstawa religii, w: Teologia religii. Chrześcijański punkt widzenia, red. G. Dziewulski, Łódź-Kraków 2007, s. 157-182, tu: s. 172-174. 
uczanie mające zastosowanie w duszpasterstwie i w nim wyłączne spełnienie. To niejako z góry zakłada odpowiedni kształt przekazu o znaczeniu moralizatorskim i pobożnościowym, który może być łatwiej przyswajany i popularyzowany. Ono też toruje drogę ku pewnym trwałym przyzwyczajeniom, które pozostają często nienaruszalne. Inna rzecz dotyczy otwartości na idee teologiczne zdolne korygować i napełniać współczesną świadomość religijną zmysłem odnowy. Równocześnie przeciwstawiać się rozmaitym mniemaniom pseudoteologicznym, zniekształcającym ducha prawdziwej doktryny kościelnej. W tym aspekcie istnieje także znacząca pasywność, która polega głównie na braku wrażliwości wobec żywej teologii, że ta właśnie wprowadza nowe spojrzenie i rozwiązania w kształtowanie stałych więzi między nauczaniem teologicznym a misją Kościoła czy ruguje błędne tendencje zwyczajowo-religijne celem prawowiernej działalności duszpasterskiej itd. Tymczasem teologia choćby miała być oprotestowana przez większość wspólnoty akademickiej zasługuje na szczególne miejsce pośród innych nauk jako „najpiękniejsza sztuka pisarska”. Tylko ona potrafi w sposób prawdziwy i entuzjastyczny mówić o Bogu i zarazem na nowo odkrywać fenomen chrześcijaństwa ${ }^{10}$.

\section{Efekt ponadkonfesyjności}

Przyczyn zepchnięcia teologii do przedmiotu niszowego pośród innych dziedzin naukowych należy upatrywać także w zmieniającym się podejściu do religii oraz akceptacji religijności w życiu społecznym. Ostatnio nastąpiły pod tym względem znaczące przeobrażenia, które wynikają z nowych i lepszych możliwości identyfikowania zjawiska religijnego w świecie dzięki między innymi rozmaitym środkom komunikacji. Jednocześnie pojawiła się wyraźna tendencja do niwelowania bądź całkowitego zacierania różnic konfesyjnych, wspólnotowych czy nawet typowo religijnych (J. Fridericks). W zamian promuje się religijność ponadkonfesyjną, czyli neutralną wyznaniowo, aby istotnie osłabić więzi z konkretnym podmiotem religijnym ${ }^{11}$. Trzeba podkreślić, że tego rodzaju intencjonalność oddziałuje wyjątkowo negatywnie na całe dziedzictwo chrześcijańskie, na które składa się zróżnicowanie wyznaniowe, jakkolwiek będzie ono pojmowane w wymiarze duchowym i soterycznym.

Próba odejścia od tradycyjnej formy wyznaniowej ma na celu podważenie dotychczasowego kształtu tożsamościowego poszczególnych wspólnot na rzecz

\footnotetext{
${ }_{10}$ Międzynarodowa Komisja Teologiczna, Teologia dzisiaj. Perspektywy, zasady i kryteria, thum. K. Stopa, Kraków 2012, s. 21-22.

${ }^{11}$ K. Kałuża, Czy teologia komparatywna zastapi teologię religii?, „Studia Oecumenica” 16 (2016), s. 319-358, tu: s. 338-339.
} 
jednej nieokreślonej społeczności religijnej. Ta z kolei jako „uniwersalna” będzie mogła skupiać w sobie nieograniczoną wielość różnych elementów wierzeniowych, lecz już niezwiązanych trwale $\mathrm{z}$ dziedzictwem historycznym ${ }^{12}$. Na tym miałyby rzekomo polegać jej autentyczność, kreatywność i nowoczesność, które zwiększą moc oddziaływania tej nowej wspólnoty. W swoim założeniu musi ona pozostawać w opozycji przede wszystkim do dawnego modelu funkcjonowania wspólnot chrześcijańskich. Interesująca rzecz, że tego rodzaju idea ,uniwersalnego zgromadzenia religijnego" znajduje dziś znaczne grono zwolenników. Oczywiste staje się zatem, że im większe parcie na wypromowanie takiej formy religijności, tym bardziej tracą na znaczeniu tradycyjne wspólnoty religijne. A wraz za tym następuje przewartościowanie w odniesieniu do wiedzy i poznania teologicznego ${ }^{13}$. Teologia jest postrzegana $\mathrm{z}$ jeszcze większą rezerwą i zaniżoną miarodajnością w zakresie twórczym i edukacyjnym.

Najtrudniej jest z pewnością w obszarze tzw. teologii specjalistycznej, rozwijanej w ramach programów uniwersyteckich, gdzie w grę wchodzi podział na wąskie specjalizacje i fragmentaryzację wiedzy. Problem ten dotyka szczególnie zawodowych teologów, ponieważ z jednej strony są oni zobowiązani zachować wierność swemu powołaniu i realizować badania naukowe wedle prawdziwych reguł postępowania naukowego, w tym całkowicie zbieżnego z normami katolickimi, a z drugiej strony pozostają pod naporem pewnych nurtów myślowych i postaw zbiorowych stojących w opozycji do tradycyjnych poglądów teologicznych. W tym wypadku nawet próby integralnego ujęcia pewnych aspektów teologicznych czy choćby teologicznej interpretacji ludzkiej rzeczywistości nie budzą większego zainteresowania. Dlatego nasuwa się pytanie, czy to przejściowy kryzys teologii i teologa w obecnych warunkach rozwoju świadomości społeczno-kulturowej.

Jeśli chodzi o miejsce teologii w wymiarze uniwersyteckim, to sprawa jest bardziej złożona i wiąże się w pewien sposób z kryzysem instytucji uniwersytetu, a wraz z nim całego środowiska akademickiego, z powodu wyrafinowanej relatywizacji wartości ponadmaterialnych. Ma ponadto związek z radykalizacją nastrojów antykościelnych i antyklerykalnych, które wywierają określony wpływ na tę społeczność. Do tego dochodzi kwestia ponadkonfesyjności, której uległość wydaje się tyle nieuchwytna co i demoralizująca. Ostatnio w Europie, w tym i w Polsce, w związku głównie ze spadkiem zainteresowania studiami sensu stricto teologicznego dokonuje się pewne przeorientowanie w dyspozycji i ofercie kierunku teologia. W wyniku tego w programie studiów pojawiają się

12 Por. G. Thils, Problemy teologii religii niechrześcijańskich, tłum. J. Kowalczyk, Warszawa 1975, s. 32-35.

${ }_{13}$ W. Klausnitzer, „,Nostra Aetate“ als Ausgangpunkt einer Theologie der Religionen, „Roczniki Teologii Fundamentalnej i Religiologii” 5 (2013) 60, s. 110-112. 
takie specjalizacje jak np. kultura chrześcijańska, teologia kultury, dialog międzyreligijny i międzykulturowy. Jednak ostatecznie nie wiadomo, czy miałyby one stanowić poszerzenie i dopełnienie dotychczasowego kanonu przedmiotów teologicznych czy jego całkowite zastąpienie nowym profilem.

Niewątpliwie owe specjalizacje mogą uchodzić za spełniające wyzwanie współczesnego ruchu ponadkonfesyjnego i w związku z tym zyskać uznanie w środowiskach uniwersyteckich. Odrębną sprawą pozostaje ich kompatybilność $\mathrm{z}$ dziedziną teologiczną oraz wiarygodne czerpanie $\mathrm{z}$ argumentacji teologicznej. Dla teologa mimo wszystko istotny jawi się problem jego tożsamości, który wiąże się nie tylko z uprawianą dyscypliną, ale i osobistym przykładem ${ }^{14}$. Wszakże spełnia on swoją misję zarówno jako naukowiec, jak i reprezentant Kościoła. Chyba że z jakichś względów nie zamierza się identyfikować ze wspólnota Kościoła, bo i takie sytuacje się zdarzają, ale wówczas jego funkcja nauczania przestaje być autentyczna. Teolog bardziej niż przedstawiciele innych dyscyplin nauki musi się liczyć z konsekwencjami etycznymi, wobec czego margines tolerancji w stosunku do niego znacznie się zawęża. Zajmując katedrę uniwersytecką, nie może zaprzestać łączności ze społecznością wierzących, bez względu na preferencje środowiska naukowego, gdyż w przeciwnym razie stałby się niewiarygodny i dla jednej, i dla drugiej strony. Oznacza to, że pod żadnym pozorem nie może wlać się w nurt ponadkonfesyjny ani być jego cichym sprzymierzeńcem.

\section{Specyfika naukowej autonomii teologii}

Teologia obejmuje zdecydowanie szerszy zakres, niż może to wynikać z planu zajęć, choć często jest postrzegana jako jeden spośród wielu przedmiotów ${ }^{15}$. To nie tylko nauka albo metoda teologicznego kształcenia, ale kategoria wiedzy rozwijająca zmysł ludzkiej wiary ${ }^{16}$. Wiara stanowi dla teologii istotną zależność, dopełnienie i podstawową wartość. Czymże byłaby teologia bez wiary? Wszak nieustannie się nią karmi i dzięki niej znajduje swój prawdziwy sens. Jeśliby pominąć aspekt wiary w teologii, jak chciałyby tego niekiedy środowiska akademickie, wówczas nastąpiłoby także pozbawienie jej przymiotu naukowości. Posłannictwem teologii jest poznawanie i głoszenie prawdy (w tym najwyższej,

\footnotetext{
${ }^{14}$ Kongregacja Nauki Wiary, Instrukcja o powołaniu teologa w Kościele „, Dominum Veritatis”, w: W trosce o petnię wiary. Dokumenty Kongregacji Nauki Wiary 1966-1994, red. i thum. J. Królikowski, Z. Zimowski, Tarnów 2010, s. 425-445.

15 W. Myszor, Teologia akademicka. Jej granice i ograniczenia, „Śląskie Studia Historyczno-Teologiczne" 43 (2010), s. 141-150.

${ }^{16}$ Por. U. Lüke, Theologie und Frömmigkeit - Gedanken über eine schwierige Beziehung, „Theologie und Glaube” 90 (2000), s. 239-250.
} 
jaką stanowi żywy Bóg), od czego nie może odstąpićp ${ }^{17}$. Na tym polega jej odmienność i specyfika naukowa, których nie można porównać czy tym bardziej zrównywać z żadną inną teorią naukową.

W praktyce okazuje się, że ta dwuwymiarowość teologii, która powoduje napięcie sama w sobie, wywołuje najwięcej kontrowersji odnośnie do swojej autonomii naukowej. Właśnie element wiary jako ściśle związany z teologią, nawet w opinii znanych współczesnych religioznawców, podważa jej charakter naukowy. Dokładnie wymiar abstrakcji obecny w wierze czyni teologię z naukowego punktu widzenia niewiarygodną. $\mathrm{W}$ interpretacji teologów zaś to dzięki tej relacji teologia jeszcze bardzie zyskuje na swej naukowości. Związek teologii $\mathrm{z}$ wiara nie deprecjonuje jej znaczenia i wartości, lecz jeszcze bardziej wskazuje na niezrównany i wyłączny (autonomiczny) charakter myśli teologicznej. $Z$ tego względu nie może być ona $\mathrm{w}$ prosty sposób utożsamiana $\mathrm{z}$ pozostałymi naukami humanistycznymi. Teologia spełnia się bowiem w podwójnym przeznaczeniu, a przy tym staje się impulsem do nieustannego przekraczania granic wiedzy człowieka o jego i świata przyszłości.

Ten rodzaj usytuowania teologii pośród innych dyscyplin uniwersyteckich nie wynosi jej ponad tamte, ani też nie izoluje wobec nich. Sprawia jedynie, że mogą one stać się dla siebie wyzwaniem interdyscyplinarnym (zwłaszcza w odniesieniu teologii do nauk filozoficznych, archeologicznych, historycznych, przyrodniczych i innych) oraz tworzyć płaszczyznę spotkania intelektualnego, refleksyjnego, porównawczego i krytycznego. Tu chodzi nie tylko o rozwijanie własnych horyzontów interpretacji natury, stworzenia, relacji, potencjału itd., ale spowodowanie, że rozeznanie człowieka na temat otaczającego go świata będzie odpowiadało jego potrzebom i dialogowi. Interdyscyplinarne komunikowanie się, zdaniem Benedykta XVI, „to otwieranie się na wielkość rozumu, a nie jego odrzucanie [...], gdzie teologia podejmująca refleksję nad wiarą biblijną wchodzi w dialog z obecnymi czasami”"18. Dla teologa otwartość na wiedzę i kompetencje innych dziedzin naukowych, to także możliwość sięgania po nowe doświadczenie i nowe światło w dążeniu do prawdy. Natomiast dla drugiej strony to szansa zaczerpnięcia $\mathrm{z}$ intuicji wskazującej często na inne niż tylko materialne znaczenie i perspektywy dociekań naukowych.

Spotkanie teologa z uniwersytecką scientific community przy okazaniu dobrej woli i chęci wzajemnej współpracy może spełniać dwojaką funkcję. Po pierwsze zmieniać ogólne nastawienie wspólnoty uniwersyteckiej w stosunku do teologii jako nauki, stanowiącej integralną część całościowej działalności uczelnianej, jakkolwiek zachowującej własną specyfikę. Jednocześnie pozytywnie wpływać

\footnotetext{
17 J. Ratzinger, Prawda w teologii, tłum. M. Mijalska, Kraków 2001, s. 62-63.

${ }_{18}$ Benedykt XVI, Wiara, rozum i uniwersytet, w: Islam a chrześcijaństwo. Konfrontacja czy dialog?, opr. P. Słabek, Kraków 2006, s. 17-32, tu: s. 30.
} 
na postrzeganie miejsca wiary i Kościoła we współczesnym świecie. Po drugie odgrywać rolę swoistego katalizatora w relacji do innych dyscyplin, które niekiedy sprawiają wrażenie całkowicie oderwanych od służby człowiekowi i niejako zawieszonych w próżni. Wynika to przede wszystkim z pragnienia indywidualizacji, zawężenia i wyodrębnienia, a wraz z tym zdystansowania, izolacji i bezwzględnej konkurencji. Ponadto, jak zauważa A. Anderwald, cała sytuacja związana z multiplikacją wyników, metod, kierunków badawczych i związane z nią trudności wewnętrznej komunikacji decydują o tym, że różne dyscypliny, włączając teologiczne, ulegają pełnej partycypacji we fragmentaryzacji nauki ${ }^{19}$. To w oczywisty sposób nie sprzyja dialogowi interdyscyplinarnemu ani dopełnianiu się w szerszym zakresie poznawczym.

Jeśli teologia ma pozostać dyscypliną naukową o istotnym charakterze relacyjnym, to musi jej niezmiennie przynależeć szczególna odpowiedzialność za właściwe kształtowanie wrażliwości naukowej środowiska uniwersyteckiego. A więc nie może się ograniczać jedynie do zachowania swego statusu i w związku z tym lepszej akceptacji na uczelni. Chodzi bardziej o ukazywanie rzeczywistych odniesień i zależności między różnymi gałęziami nauk, a zwłaszcza humanistycznymi. Ważne jest poszukiwanie nowych możliwości i obszarów współpracy przez tworzenie odpowiedniego klimatu komunikacji, do czego teologia ma naturalne predyspozycje, a nie zamykanie się w obawie przed jeszcze większym przejawem niezrozumienia czy sceptycyzmu we wspólnocie akademickiej. W końcu istotne jest wnoszenie własnego wkładu w budowanie wzajemnego porozumienia i prawdziwej wspólnoty.

Obecność teologii i teologa we wspólnocie akademickiej stanowi dzisiaj wyzwanie szczególnej wagi. Jednym $\mathrm{z}$ istotnych powodów są transformacje ustrojowe w krajach postkomunistycznych Europy w ostatnim ponadćwierćwieczu, jak również przemiany o charakterze ideowo-aksjologicznym na Zachodzie naszego kontynentu. Wszystkie te procesy dotknęły wiele sfer życia społecznego, kulturowego, duchowego, mentalnego, a ponadto związanego bezpośrednio z kształtowaniem współczesnej myśli teologicznej. Owszem teologia i teologowie zdobywają potencjalnie nowe możliwości rozwoju i oddziaływania w przestrzeni uniwersyteckiej, zwłaszcza tam, gdzie wcześniej było to zakazane. Jednak w praktyce, o czym wyżej było dokładniej, zaczynają się pojawiać coraz większe trudności w ich akceptacji. Problem bynajmniej nie jest jednostronny ani nie dotyczy wyłącznie strony niezwiązanej z teologią w środowisku akademickim,

19 A. Anderwald, Teolog a scientific community. Wzajemne odniesienia, przyczyny, w: JaWspólnota. Perspektywa teologii fundamentalnej, red. E. Kotkowska, J. Moskałyk, Poznań 2009, s. 144. 
lecz wiąże się także z profilem naukowym teologii i odpowiedzialnością samych teologów.

\section{Today's presence of a theologian and theology in the academic community}

\section{Summary}

The presence of theology in the academic community is today a challenge of particular significance. One of the most important reasons are political transformations in the post-communist countries of Europe in the last 25 years, as well as ideological and axiological transformations in the West of our continent. All these processes have affected many spheres of social, cultural and spiritual life and are directly related to shaping the contemporary theological thought. Although theology acquires potentially new opportunities for development and impact in the university space, in practice there are increasing difficulties in its affirmation. The problem primarily concerns the scientific profile of theology and the responsibility of theologians themselves.

\section{Keywords}

theologian, theology, academic community, autonomy of theology, supranational confession

\section{Slowa kluczowe}

teolog, teologia, wspólnota akademicka, autonomia teologii, religijność ponadkonfesyjna

\section{Bibliografia}

Anderwald A., Teolog a scientific community. Wzajemne odniesienia, przyczyny, w: JaWspólnota. Perspektywa teologii fundamentalnej, red. E. Kotkowska, J. Moskałyk, Poznań 2009, s. 131-149.

Benedykt XVI, Wiara, rozum i uniwersytet, w: Islam a chrześcijaństwo. Konfrontacja czy dialog?, opr. P. Słabek, Kraków 2006, s. 17-32.

Bernhard R., Ende des Dialogs? Die Begegnung der Religionen und ihre theologischen Reflexion, Zürich 2005.

Kałuża K., Czy teologia komparatywna zastapi teologię religii? „Studia Oecumenica” 16 (2016), s. 319-358.

Klausnitzer W., „Nostra Aetate“ als Ausgangpunkt einer Theologie der Religionen, „Roczniki Teologii Fundamentalnej i Religiologii” 5 (2013) 60, s. 99-115. 
Kongregacja Nauki Wiary, Instrukcja o powołaniu teologa w Kościele „Dominum Veritatis”, w: W trosce o petnię wiary. Dokumenty Kongregacji Nauki Wiary 1966-1994, red. i tłum. J. Królikowski, Z. Zimowski, Tarnów 2010, s. 425-445.

Lüke U., Theologie und Frömmigkeit — Gedanken über eine schwierige Beziehung, „Theologie und Glaube” 90 (2000), s. 239-250.

Międzynarodowa Komisja Teologiczna, Teologia dzisiaj. Perspektywy, zasady i kryteria (2012), tłum. K. Stopa, Kraków 2012.

Myszor W., Teologia akademicka: Jej granice i ograniczenia, „Śląskie Studia Historyczno-Teologiczne" 43 (2010), s. 141-150.

Nossol A., Znaczenie ekumenizmu dla wychowania w sytuacji pluralizmu światopogladowego i religijnego, „Paedagogia Christiana” 8 (2001) 2, s. 29-34.

Olszewski M., Teologia jako nauka wedtug Tomasza z Akwinu jak też o pożytkach ptynacych z czytania średniowiecznych tomistów, w: Teologia św. Tomasza z Akwinu dzisiaj, red. B. Kochaniewicz, Poznań 2010, s. 137-150.

Ratzinger J., Prawda w teologii, thum. M. Mijalska, Kraków 2001.

Roszak P., Dwie prędkości teologii? O celu, metodzie i perspektywach teologii analitycznej, ,Teologia w Polsce” 9 (2015) 2, s. 75-93.

Rychlicki C., Miejsce i rola teologii w formacji chrześcijańskiej, „Teologia i człowiek” 1 (2003), s. 105-122.

Rychlicki C., Proces Boloński. Dziedzictwo kulturowe i wartości akademickie Uniwersytetów Europejskich, „Roczniki Teologiczne KUL” 54 (2007) 2, s. 231-235.

Rusecki M., Objawienie Boże podstawa religii, w: Teologia religii. Chrześcijański punkt widzenia, red. G. Dziewulski, Łódź-Kraków 2007, s. 157-182.

Thils G., Problemy teologii religii niechrześcijańskich, tłum. J. Kowalczyk, Warszawa 1975.

Werbick J., Wissenschaftlich oder kirchlich? Eine Positionsbestimmung der Theologie, „HerKor” Speziel 2 (2008), s. 2-6. 